\title{
Varia
}

\section{Pappenheim-Preis 1973}

Anlässlich der 79. Tagung der Deutschen Gesellschaft für Innere Medizin ver-lieh die Deutsche Gesellschaft für Hämatologie den Pappenheim-Preis 1973, der von den Nordmark-Werken Hamburg mit einem Geldbetrag dotiert wird, an Dr. Götz Kaiser, Dr. Dietrich Gauger und Dr. Klaus Quiring (Zentrum der Pharmakolo-gie, Klinikum der Universität Frankfurt) für ihre Arbeit «Der Retikulozyt als zellu-läres Modell eines adrenergischen /?-Rezeptor-Effektor-Systems». International Society of Haematology

The 3rd Meeting of the European and African Division of the International Society of Haematology will be held in London at the Royal Festival Hall, on August 24-28, 1975. President: Prof. J. V. Dacie. Secretary: Dr. S. M. Lewis.

The scientific programme will include reviews, presentation of new work, round table panel discussions on pratical aspects of the subjects and workshops on specialized topics. The main sessions will be on the following topics: hereditary haemolytic anaemias; thrombosis and haemostasis; immuno-haematology; erythro-poiesis, aplastic anaemia; leukaemia; haemoglobin, thalassaemia, haemoglobino-pathies; nutritional anaemias; lymphomas, myeloma. There will be an exhibition of technical equipment, laboratory instruments and pharmaceutical products. There will also be scientific demonstrations and scientific film shows. The official language of the meeting will be English. Further information can be obtained from: Dr. S. M. Lewis, Department of Haematology, Royal Postgraduate Medical School, Ducane Road, London, W12 OHS (England). 